\title{
Oil price reduction impacts on the Iranian economy $^{* 1}$
}

\author{
Abdollah Mahmoodi ${ }^{2}$
}

\begin{abstract}
The aim of this study is to assess the impacts of oil price reduction on Iran's economy. In order to simulate this shock, the global trade analysis project (GTAP) model with its data done by using. In the new created data aggregation, oil exporting in Iran and the rest of the world countries as economic new regions, ten new economic sectors have been created, among which the oil is introduced as one sector as well as five endowments. The standard economic closure was changed, and decline in world oil price was simulated in model as a policy shock. The results show that oil export revenue and the mineral commodity export earnings will decrease, but other production sectors' exports will increase. The trade balance of Iran will be affected negatively and strongly. Also, oil and other services production decreased. In the production sectors' market, the demand for labor, natural resources, and investment decreased dramatically, and the demand for land increased. Using equivalent variation (EV), changes in Iran's welfare is high negative. Finally, deflation, reduction in value and quantity of GDP and changes in consumption combination from public to private sector are the other economic impacts of reduction in oil price on Iran's economic. It is suggested that future studies are done using dynamic models and up-to-date data. In addition, policy makers need to rebound internationally and within OPEC to raise oil prices.
\end{abstract}

Key words: oil price, Iran's economy, consumption combination, welfare, labor market

JEL classification: F17, I30, J23, Q31, C68

* Received: 25-04-2017; accepted: 21-12-2017

1 This research has been supported by Mahabad Branch of Islamic Azad University under the funding program Independent research projects of Islamic Azad University, code 51662931101001, contract number 02-29-5/678.

2 Assistant Professor, Mahabad Branch, Islamic Azad University, Collage of Humanities, Pazhuhesh sq, Mahabad, Western Azerbaijan, Iran. Scientific affiliation: economics. Phone: +98914442 0209.E-mail:mahmoodi_a2000@yahoo.com. 


\section{Introduction}

The price of oil is determined in international markets, and since it affects export incomes of oil-rich countries, it can be effective on economic variables of these countries. In these countries, oil revenue which enters the budget of national governments is effective on their communicational, educational, health, welfare and defense infrastructures, and on the other hand as government expenditures it has great effect on consumption, production, income distribution, health and training, the incomes of government employees that form heavy share of workforce of such big governments.

Traditionally, Iran is one of the oil exporting countries. Since the beginning of oil production in Iran, in addition to being the basis of many social and political events, this raw material has been significantly effective on different economic variables such as labor market, import and export, government budget, industry and agriculture and even services. Moreover, the oil has changed social and cultural texture of the country as well. The type of consumption, heavy volume of urbanization, changing the combination of national production from agricultural to service and industrial and many other changes of recent century are directly or indirectly dependent on oil.

Historical changes of oil price have shown it has been valorized increasingly. Of course in addition to that its price has been slowly increasing; it has increased in some years so that it has been considered as historical milestones in the industry and energy. Great shock of oil price started in 1972 and reached its peak in 1980, then it takes upward trend till in 2009 which it has the highest price of history. The economy of Iran in these years suffers from severe inflation. Then oil price again decreases and in 2014 it has been fluctuated in the range of 47 to 60 dollars per barrel. The rise of oil prices in late first decade of the $21^{\text {st }}$ century and then returning to first half of second decade have brought some consequences for the economy of oil-rich countries ${ }^{3}$, so this research is sought to identify these consequences in Iran.

Iran's economy is passing through its stagflation period. Economic growth rate is negative (growth with oil in 2013 about -2.2 and without oil -2 percent). ${ }^{4}$ The unemployment rate more than $12 \%^{5}(21 \%$ in 2011 and $20 \%$ in 2012), severe inflation (50.76 in 2012, 41.2 in June 2013 and 14.2 in June 2014), poor foreign investment, high importing and mainly consumption one, mainly traditional and oil exporting, severe decline in financial indexes (Tehran Stock Exchange: total index

\footnotetext{
$\overline{3}$ Resource: http://www.macrotrends.net/1369/crude-oil-price-history-chart date: 06/24/2015

4 Iran statistics center: http://www.amar.org.ir/default.aspx?tabid=1822 date 06/28/2015

5 Central Bank of the Islamic Republic of Iran
} 
from about 89500 in $01 / 05 / 2014$ to 64300 in $06 / 28 / 2015^{6}$, also Gini coefficient has been fluctuated in range of $41 \%$ (2010) to $37 \%$ in $2013^{7}$. It has to be said that at least in recent decade the government has been faced with budget deficit and negative non-oil trade balance has been in fluctuation at least from 2001 to first quarter of 2013 in the range of 12 to 38 billion dollars ${ }^{8}$.

The value of all mentioned variables and other variables of Iran's economy shows that recession and stagnation can be seen in all economic sectors. There are many reasons for these adverse economic conditions such as drought, incompetent economic management, chore international sanctions and following that severe decrease of exporting oil as well as governmental and quasi-governmental structure of economic ownership and somehow rentity economy but the effect of severe decrease of oil price cannot be ignored. This importance gets double when a heavy share of government budget is provided by oil incomes (44\% in 2013). This research is sought to respond this question which discusses what effect falling oil price has on Iran's economy variables and to what extent. The main hypothesis of study is that: the decline in oil price has a significant negative impact on Iranian economy. The main purpose is to analyze the impacts of oil price cuts on economic variables, including private and public consumption and changes in the composition of them; households' utility and welfare in Iran; GDP and each economy sectors' production; production factors' market; exports, imports and trade balance.

The study's contributions to literature are, first, it examines the impacts of reduction in oil price on public and private consumption and their domestic and imports combination, welfare, economy sector's production changes, and Iran's international trade. Second, oil price changes have very sophisticated serial effects on economic variables, our aim is to specify these effects in a general equilibrium condition by using a new and trade related methodology.

After this introduction, the next section presents the literature review, and after that, the methodology section will illustrate some $\mathrm{CGE}^{9}$ equations that reflect changes in economic variables, fourth section is empirical data and analysis, which explains the source of data, changes in economic closure and economic shock variable to simulate changes in oil price. The policy simulation results are presented in section five and finally, section six is study conclusion.

\footnotetext{
6 Technology Management Co. and the Tehran Stock Exchange http://www.tsetmc.com/Loader.aspx? ParTree $=15131 \mathrm{~J} \& \mathrm{i}=32097828799138957$

7 Iran statistics center: www.amar.org.ir date 06/28/2015

${ }^{8}$ Iran customs statistics

9 Computable General Equilibrium
} 


\section{Literature review}

There is a wide range of CGE models that have explained the impact of economic variables' shocks on an economy such as the Esmailpouri et al. (2017) $\operatorname{DSGE}^{10}$ for Iranian economy and Bodenstein et al. (2013) model, but to measure the policy shocks impacts on economy of Iran that oil is an important variable; Afshari (2013) described the relationships between all economic variables well. Oil shocks, positive or negative, the price or value, affect economic activities of the exporting country. Their effect will be on both supply and demand of economy. With decreasing the price of oil, the government decreases importing of goods and services and apply foreign currency savings and allocate that only to necessary needs, the repayment of loans and foreign commitments. In countries that main part of their imports are capital goods, exchange limitation will lead to decreasing importing such goods, decreasing the investment and the production capacity and finally it will be followed by supply constraints and rising prices that will lead to decreasing the consumption of final goods and household welfare.

Oil price enables the import of consuming goods, intermediate commodities and even exporting some of goods and services that affects international trade balance. Earnings of crude oil will enter the budget of government and cover main developmental and current costs of government. The government will be abler to employ production factors and it affects the market of production factors such as labor market. Government expenses will expand economy. The government purchased goods will motivate domestic production sectors and it will be followed by economic prosperity. Moreover, giving payment to huge number of government staff, increases consuming the goods and services and in addition to increase family welfare, it will have double effect on producing the domestic and imported commodities and it will affect foreign trade.

The entry of foreign currency resulted by selling oil and the exports derived from induced boom of the oil sector to other economic sectors and oil sector itself with positive sign and importing three types of goods negatively that their importing has been reduced because of falling oil price, will affect trade balance. The effect of oil price on each of variables and moreover its effect on the volume and value of international trade of the country will be different (Afshari, 2013; summary of third chapter).

Falling oil price will make investment and production in oil section motiveless and some of extraction and producing crude oil projects will lose economic justification. This phenomenon will also make problem for entering capital goods and technological and reduce the production of oil for double. The induced effects of oil exports on oil downstream and upstream industries and other economic sectors will

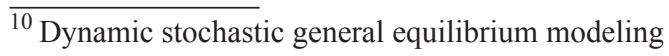


also make problem for production boom of these sectors. Production subsidies of other sectors will reduce, production cost will increase and the profit of economic activities will decrease. Moreover, it restricts government in expansionary fiscal policies, consuming public and private goods by households will reduce and it will be followed by economic recession in all economic sectors.

By decreasing activities in various economic sectors as well as lack of government income resources, the demand for labor reduces; unemployment will increase through fixed payments or in existing employment level, real payments will decrease. The demand for other production factors will also decrease because of stagnant oil sector activities in other economic sectors and government. Fewer natural resources will be used, investment will decrease in production sectors and expansion and creating of new firms will be stopped or decreased significantly.

Falling oil price with decreasing export value will have negative effect on national expenses, national consumption and utility and welfare. Because of economic activities stagnant, government tax revenues will be also negatively affected. Decreasing government income from oil and tax causes decreasing the production of public goods and decreases the private household consumption from public goods. In other side, decreasing government income will lead to decreasing transferred payments and affects the poor's welfare. Reduced transferred payments also in production section will cause decreasing the profit of production and then the income of private sector households and affect their consumption. Decreasing oil and tax revenues of government will cause government to apply restrictive policy in the section of current costs and causes decreasing the income and consumption of government's employees. Government purchases also will lead to decreasing the production and the profit of private firms through current expenditures and government capital formation costs, so will affect the income and welfare of private sector households.

Decreasing exchange earnings causes consuming and capital goods which imported and the bundle consumed by people decrease because of importing goods. Lack of new technology and capital goods decreases production and the profit of firms and then the income of families and their consuming bundle and ultimately their welfare will be decreased. Falling oil price will affect the export of some goods and in addition to decreasing income of oil export, other foreign incomes will also decrease. Decreasing of exporting commodities and investment will be followed by stagnant and lead to decreasing the wages or unemployment of production factors and it will cause national and per capita income to be reduced.

Due to affectability of economic variables from changing oil price, some studies have been conducted. Motevasseli and Fooladi (2006) consider rising oil price as the factor of increasing GDP. Sadeqi et al. (2013) believe that instability of oil price (Behboudi et al., 2009; in long term) will affect GDP negatively. Delavari et 
al. (2009) have concluded that oil shocks have asymmetrical effect on the growth of GDP and falling oil price will be more effective on GDP than increasing it. According to Samadi et al. (2013) permanent fluctuations of oil price will result in decreasing production and investment and also rising oil price increases industrial production (Samadi et al., 2009). Abrishami et al. (2009) believe that falling oil price will have severe effect on economy negative growth in OPEC. Mehrara and Niki Oskouei (2006) consider oil shocks as the most important factor if GDP fluctuations in Iran and Saudi Arabia and Mehragan et al. (2013), Samadi, Hadian and Jafari (2013) consider oil shocks as the reason of economy low growth in Iran. Saeideye (2004) believes that falling oil price is the factor of decreasing agricultural and industrial production but it increases a little service production and Monjazeb et al. (2013) consider rising oil price as the factor of growing GDP and vice versa. Emami and Adibpour (2012) believe that negative and positive oil shocks will directly affect the growth of national production. Salehi Isfahani, Mohadeth et al. (2009) believe that oil export in Iran affects production growth through capital accumulation. Esmaeilipour et al. (2017) showed that rising oil prices will increase Iran's production in the short run, and (Shariati et al., 2013) D8 countries' economic growth. Wang et al. (2016) believe that falling oil prices boost economic growth of China as an oil importing country. Finally, in Gulf Cooperation Council (GCC) positive changes in oil prices will increase real GDP and vice versa, but positive oil price changes have a larger effect on that than negative changes (Nusair, 2016). Zhao et al. (2017) indicated that different sources of oil price shocks have different effects in size and time on output and inflation in China.

Moqaddam and Sazvar (2012) consider oil shock as the main source of inflation. Ebrahimi et al. (2010) believe that rising oil price increases consumer price index and (Rabie Hamadani et al., 2015) inflation. Samadi et al. (2009) and Esmaeilipour et al. (2017) consider rising oil price as the reason of inflation and Saeideye (2004) consider falling oil price as the reason of inflation. About the effect of oil price on employment, Motevasseli and Fouladi (2006) consider rising oil price as the reason of increasing whole employment and (Rabie Hamadani et al., 2015) the employment in oil and gas sectors, building and services in Iran. Samadi et al. (2013) believe that the fluctuations of oil price increases unemployment rate in the members of OPEC and it is also considered in Iran as the reason of unemployment (Samadi, Hadian and Jafari, 2013). Pashaeifam et al. (2013) showed that, oil price increases cause inflation in OECD as oil-importing countries.

Regarding the effect of oil price on the consumption of governmental and private sectors, current account and income, household expenditure and welfare, the study of Ebrahimi et al. (2010) shows rising oil price increases current expenditures and capital formation of government. Oil price shocks also have high effect on the expenditures of governmental sector (Ghiasvand and Yahoo, 2010). Gozali (2011) believes that the level of oil price has high effect on government consumption and 
investment in Indonesia. Memarzadeh (2017) showed that the public and private consumption response varies by changing oil prices. The positive momentum of oil price has increased the consumption of private sector and total investment, but the government's final consumption has shown a negative reaction that has been meaningful for only a single period. Finally, Farzanegan (2011) considers that Iran's military and security expenditures significantly respond to a shock in oil prices, while private expenditure does not show significant reactions to such shocks. In addition, oil revenue (price) does not affect investment in Iran in the long run (Dreger and Rahmani, 2014).

Moreover, Arani et al. (2010) consider rising oil price as the factor of increasing current account balance and decreasing that has a reverse effect on it. The study of Neamatollahi and Tabatabaei (2009) and Majdzadeh (2013) showed that the instability of oil price has negative and significant effect on OPEC trade balance but Samadi et al. (2009) consider rising oil price as the reason of increasing imports in Iran and Saeideye (2004) knows falling oil price as the factor of increasing the imports and exports of all sectors. Hasanzadeh et al. (2012) also believe that the fluctuations of oil price affect income, urban household welfare and expenditure more than rural household and rising oil price has more effect than decreasing it. Falling oil price has equal pressure on the poor and the rich in Iran. Finally, oil importing and consuming countries are more sensitive to oil price shocks than oil production. The Iran's macroeconomic variables (GDP, CPI, and unemployment) influenced by oil price shock and there is a co-movement between oil price and macro variables (Ju et al., 2016).

\section{Methodology}

There are many models to assess the effects of oil price on economic variables, but the CGE models offer advantages that separate these models from the rest, and making them powerful in economic analysis. The CGE models are systematic, comprehensive and appropriate for a big wide of investigation such as changes in trade policies. They are able to capture links between the industries, primary factor and commodities in domestic economy, and between the domestic and the rest of the world's economy. Global Trade Analysis Project (GTAP) is one of the branches of CGE models, which was established to conduct quantitative analyses of international economic issues in an economy-wide framework, which consists of several components: a global data base, a standard GE framework, and software (Hertel, 1997). GTAP uses standard neoclassical assumptions: output and factor markets are in perfect competition; production function in all activities uses constant returners to scale technology; consumers and firms maximize their target functions; and all of the markets are in clearing condition. 
To follow the research objectives, and to simulate the shock of oil price reduction, GTAP model is used. In this section only the equations that transfer the impact of policy shocks to the variables considered in this research, will be explained. In order to explain the effects of falling oil price, consider falling in global price of exported good $(i)$ from Iran $(r)$ entered to area $s$ (oil importing countries), PM (i, $r$, $s$ ). Equation $l$ is used to determine total sale of good $i$ from region $r$ to region $s$ that has happened because the reaction of firms in region $s$ to price shock:

$$
\begin{aligned}
& V O M_{i r} * q o_{i r}=V D M_{i r} * q d s_{i r}+V S T_{i r} * q s t_{i r}+ \\
& +\sum_{s \in R E G} V X M D_{i r s} * q x s_{i r s}+V O M_{i r} * \text { tradslack }_{i r}
\end{aligned}
$$

Here $V O M$ is total value of production to market price, qo total production, $V D M$, $V S T, V X M D$ and tradslack are respectively sales of domestic products at market prices, transportation export, the value of exporting good $i$ from $r$ to $s$ at market price and auxiliary variable in the condition of tradable commodities market clearing. The value of exporting tradable good $i$ is from source $r$ to destination $s$, $\operatorname{VXWD}(i, r, s)$ and it is proposed in global market and transport margin is added to it $\operatorname{VTWR}(i, r, s)$ that gives us the value of imports in destination $\operatorname{VIWS}(i, r, s)$

$$
V X W D(i, r, s) \pm V T W R(i, r, s)=\operatorname{VIWS}(i, r, s)
$$

Existing values in equation have been obtained from multiplying the values in relevant prices:

$V=p \cdot q$ and based on changes:

$$
d V / V=\frac{d(P Q)}{P Q}=p+q
$$

Here $p$ and $q$ are respectively percentage changes of price and value that in the equation above, the value of exports is equal to $Q S$ and its price is $P C I F$. In general equilibrium model, price is an endogenous variable that is the effect of changing in exogenous variables will be reflected on them. GTAP model shows these changes as the percentage of changing and absolute measure (based on value) of changing from initial value. Because the goal of this research is investigating the effect of changing price on other variables, it is necessary to change economy closure method. In other word it is essential to consider the variable of global price which is endogenous as exogenous and corresponding values which are exogenous as endogenous (Mahmoodi, 2015: first part, Hertel, 1997).

Before the changes in standard closure method, first considering theoretic statement of policy shock effect on economic variables, the equations of these effects will be briefly explained. 
Falling world oil price will lead to decreasing exports and export revenues in fixed export values. Decreasing export incomes will have negative effect on trade balance of the country which exports oil. The equations which determine changes in total value of trade, price and value indexes:

$$
\begin{aligned}
& V X W_{i r} * v x w f o b_{i r}=\sum_{s \in R E G} V X W D_{i r s} *\left[q x s_{i r s}+p f o b_{i r s}\right]+ \\
& +V S T_{i r} *\left[q S t_{i r}+p m_{i r}\right]
\end{aligned}
$$

That $v x w f o b^{11}$ is the value of local exporting tradable commodity based on good type at $f o b$ price. Changing in the price of exports will lead to change in $V X W$. This changing of export value based on commodity and region will be calculated for all goods based on region and based on good for all regions in the world. Equation 5 calculates percentage changing of the total value of world trade:

$$
V X W L D * v x w l d=\sum_{r \in R E G} V X W R E G_{r} * v{ }^{\prime} w r e g_{r}
$$

That $V X W L D$ is the value of exporting commodity at $f o b$ price and is obtained from changing in the total regions. Equation 6 also calculates the percentage of changing the value of global production based on good:

$$
V W O W_{i} * \text { valuew }_{i}=\sum_{r \in R E G} V O W_{i r} *\left[p x w_{i r}+q o_{i r}\right]
$$

That $V W O W$ is the value of global supply of trade item to world price. Equation 7 is used for calculating the change of trade balance based on region and commodity. This is a valuable concept and DTBAL (ir) reflects changing in current account of each region.

$$
D T B A L_{i r}=\left[\frac{v x w_{i r}}{100}\right] * v x w f o b_{i r}-\left[\frac{v x w_{i r}}{100}\right] * v i w c i f_{i r}
$$

That $v i w$ and $v x w$ are percentage change of imports and exports value respectively to $C I F$ and $F O B$ prices.

According to Stolper - Samuelson theory, when the price of exports falls, it is expected that the values of exporting commodities decrease, production decrease and therefore the demand for production factors decrease which have specialty in this sectors. In other words, if this sector is labor intensive, the demand for labor will decrease and as result wage ( $p f e$ ) will decrease and if this production sector is capital intensive, interest rate will decrease. All these changes will happen in the

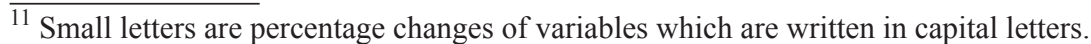


added value of production network. The equations of this part are from two types, first type elasticity of substitution equations among data inside CES production network and second type is the price function that determines the unit cost of each commodity. Equation 8 is used in order to determine the value of selling good $i$ from region $r$ to region $s$ that is occurred because the reaction of firms in region $s$ to price shock.

$$
q x s_{i r s}=\operatorname{qim}_{i s}-\sigma_{M_{i}} *\left[p m s_{i r s}-p i m_{i s}\right]
$$

That qxs is the export sales of good $i$ from region $r$ to $s$, pms and pim are respectively domestic price of commodity $i$ supplied from region $r$ to region $s$ and combined imports market price of good $i$ in region $r$. The $\sigma_{M}$ is also elasticity of substitution among the imports of various goods.

Production of sector $i$ in region $r\left(q o_{i r}\right)$ is multiplied in the supply price of that commodity in that region $\left(P S_{i r}\right)$ and the value of commodity $i$ produced in region $r$ will be obtained to the price of production and through the intervention of tax and subsidies $\left(P T A X_{i r}\right)$ the value of production good to the market price $V O M_{i r}$ will be obtained. Equation 9 shows the value of produced goods:

$$
Q O(i, r)=Q D S(i, r)+Q S T(i, r)+\sum_{s \in R E G} Q X S(i, r, s)
$$

That $q d s$ and qst are respectively domestic sale of commodity $i$ and selling to international transportation sector and $q x s$ is exporting commodity $i$ to various regions of the world $(s)$. Decreasing exports will lead to decreasing domestic production sales, decreasing added value and production factors.

$$
q f e_{i j r}+a f e_{i j r}=q v a_{i r}-\sigma V A_{j} *\left[p f e_{i j r}-a f e_{i j r}-p v a_{j r}\right]
$$

It explains the added value network. This equation presents conditional demand for endowments $(q f e)$ in each sector. In this equation the variables of price $\{p f e(i, j$, $r)\}$ include the variables that control the rate of primary factors of production and technical changes (afe $(i, j, r)$ include the rate of changing in the variable of $A F E$ $(i, j, r)$ that $A F E(i, j, r)^{*} \operatorname{QFE}(i, j, r)$ is equal to effective data of primary factor $i$ in sector $j$ in region $r$. Equation includes the below effects: through the right side of equation, the replacement of production $i$ factor is encouraged instead of other primary factors and through the left side of equation, demand curve for $i$ (in effective fixed prices) is shown. $Q v a$ is also added value of industry $j$ in region $r$ and $p v a$ is the price of added value in the same industry.

Equations (9) and (10) have presented the added value and in next branch final production as well as supply production for various types of consumption. Total production of economic sectors and public one is proposed in $g d p$. The variable $q g d p(r)$ is quantity index for domestic production. 


$$
q g d p_{r}=v g d p_{r}-p g d p_{r}
$$

It shows that value index, $v g d p(r)$ is calculated from the expenditures of government sector, private sector, gross investment and the expenditures on transport commodities. Solved value $q g d p(r)$, which reflects the changes of production possibility frontier of economy resulted from improving the allocation of a fixed source or endowment growth, proposes the summary of that region's economic growth.

In GTAP model for measuring welfare, changes in equivalent variation [EV(r)] of each region that occurs because of policy simulation is measured:

$$
E V(r)=u(r) * I N C(r) / 100
$$

Because $u(r)$ reports per capita welfare, equation 12 also includes the rate of changes in population in right side (pop $_{\mathrm{r}}$ ) so that reported EV by model shows total welfare of the region.

$$
E V_{r}-\left[\frac{I N C_{r}}{100}\right] *\left[\text { URATIO }_{r} * \text { POPRATI }_{r}\right] *\left[u_{r}+\text { pop }_{r}\right]=0
$$

Changing the equivalent of whole world (WEV) is obtained from simple add of regional $\mathrm{EV}$ in equation 13.

$$
W E V-\sum_{r \in R E G} E V_{r}=0
$$

The other price and value suitable indexes which are applied in model include gross domestic production (GDP) and the income. In order to determine quantity indexes, value and the indexes of corresponding price are needed to be first calculated because various goods are formed as a total. For example, variable $q g d p(r)$ in equation 11 is quantity index for domestic production but value index $v g d p(r)$ is first calculated in equation 15 that measures the changes of prices and quantities and another price index $p g d p(r)$ is obtained in another equation that only calculates the changes of price then quantity index $q g d p(r)$ is obtained from the difference between $v g d p(r)$ and $p g d p(r)$.

$$
\begin{aligned}
& G D P_{r} * v g d p_{r}=\sum_{i \in T R A D} V G A_{i r} *\left[p g_{i r}+q g_{i r}\right]+\sum_{i \in T R A D} V P A_{i r} *\left[p p_{i r}+q p_{i r}\right] \\
& +R E G I N V_{r} *\left[p c g d s_{r}+q c g d s_{r}\right]+\sum_{i \in T R A D} \sum_{s \in R E G} V X W D_{i r s} *\left[p f o b_{i r s}-q x s_{i r s}\right]+ \\
& \sum_{i \in T R A D} V S T_{i r} *\left[p m_{i r}+q S t_{i r}\right]-\sum_{i \in T R A D} \sum_{s \in R E G} V I W S_{i r s} *\left[p c i f_{i r s}-q x s_{i r s}\right]
\end{aligned}
$$


In trade simulations and the changes of some domestic policies, solved value of $q g d p(r)$ that reflects the changes of production possibility frontier of economy resulted from improving the allocation of a fixed source, will be less.

In which $V G A, V P A, V X W D, V I W S, p c g d s$ and $q c g d s$ are respectively the value of consuming expenditures of government, private sector, exporting commodity $i$ from region $r$ to $s$, importing the commodity $i$, the price of capital goods in region $r$ and the producing capital commodity in region $r$.

\section{Empirical data and analysis}

GTAP model is a package of world economic regions, sectors, and production factors. In new created aggregation, one of the economic region is considered Iran, second one, other countries which export oil and the third, other available countries in database. There are 57 types of goods in GTAP software and they can be classified in 10 or less commodity groups. Due to that oil export and its world price are studied here, oil is placed in one commodity group and other commodities in other nine groups. The software contains five factors of production: land, skilled and unskilled labor, capital and natural resources in which labor as well as mobile, capital and land and natural resources are sluggish.

This research aims to investigate the effects of falling world oil price $(\mathrm{pm})$ on Iran's economic variables. In policy simulation, the shock is needed to be applied on world price of oil $(\mathrm{pm})$ which is one of endogenous variables so it has to be changed to exogenous one. Therefore, standard closure method in GTAP model should be changed (Mahmoodi, 2015: 218). Policy shock was simulated in current research through this method that oil price has fallen from the highest value to 35 dollars per barrel. This falling is almost 73 in percentage but here we consider policy shock as 45 percent of falling not to reduce the accuracy of the model results.

The variables whose changes are considered important for Iran's economy are endowments demand, macro variables, trade variables, economic sectors, income distribution, welfare and household utility.

Trade variables: exports, imports and trade balance are the most important trade variables. Table 1 shows that how the exports various sectors in Iran's economy are affected by this policy shock. The first column is the quantity of exports before shock that in first line, the quantity of crude oil exports is considered as 32354 million US dollars. In second column the quantity after oil price shock has been applied that shows severe decrease in oil exports of Iran. Third column shows decreased quantity of Iran's oil export after oil world price falling (22868 million US dollar) and fourth column in this very line shows the percentage of this reduction as 71 . The most important industrial sector that has been decreased as result of global oil price falling is mining that includes five subsectors of jungle, fisheries, coal, natural gas and mining. 
Table 1: Changes in quantity of exports

- in US Million \$

\begin{tabular}{|l|l|r|r|r|r|}
\hline \multirow{2}{*}{ Industry } & \multicolumn{2}{r|}{ Impacts } & \multicolumn{2}{r|}{ The quantity } & \multicolumn{2}{c|}{ Changes } \\
\cline { 3 - 6 } & & Pre Shock & Post Shock & Quantity & Percentage \\
\hline Crude Oil & Oil $^{*}$ & 32354 & 9486 & -22868 & -71 \\
\hline Meat and Livestock & MeatLstk & 1312 & 2075 & 763 & 58 \\
\hline Mining and Extraction & Extraction & 356 & 75 & -281 & -79 \\
\hline Processed Food & ProcFood & 373 & 570 & 197 & 53 \\
\hline Textiles and Clothing & TextWapp & 981 & 1825 & 844 & 86 \\
\hline Light Manufacturing & LightMnfc & 467 & 823 & 356 & 76 \\
\hline Heavy Manufacturing & HeavyMnfc & 6910 & 27609 & 20699 & 300 \\
\hline Utilities and Construction & Util_Cons & 473 & 896 & 423 & 89 \\
\hline $\begin{array}{l}\text { Transport and } \\
\text { Communication }\end{array}$ & TransComm & 1362 & 2132 & 770 & 57 \\
\hline Other Services & OthServices & 481 & 787 & 307 & 64 \\
\hline
\end{tabular}

Note: The terms of this column are abbreviated to the 10 aggregated economic sections of the first column, which are also used in some of the following tables.

Source: Author's calculation

Table 2 shows the effect of policy shock on trade balance of various economic sectors in Iran and the countries which export oil. Decreasing Iran trade balance in oil sector has been about 26 US billion dollars and this decrease has been about 288 billion dollars for other countries which export oil. Both two groups of countries have been faced with negative changes in trade balance in mining sector. Total trade balance has faced decrease and it shows that through stability of imports, export value has been significantly fallen.

Table 2: Changes in trade balance of economic sectors

- in US Million \$

\begin{tabular}{|l|r|r|r|}
\hline Industry & \multicolumn{1}{|c|}{ Iran } & \multicolumn{1}{c|}{ Oil Exporting Countries } & \multicolumn{1}{c|}{ Rest of the World } \\
\hline Oil & -25909 & -287553 & 319636 \\
\hline MeatLstk & 815 & 2021 & -2696 \\
\hline Extraction & -1039 & -10273 & 11242 \\
\hline ProcFood & 619 & 2926 & -3316 \\
\hline TextWapp & 802 & 6138 & -6759 \\
\hline LightMnfc & 1555 & 23995 & -25118 \\
\hline HeavyMnfc & 20191 & 239606 & -264739 \\
\hline Util_Cons & 385 & 1667 & -2055 \\
\hline TransComm & 517 & 11708 & -14518 \\
\hline OthServices & 578 & 13020 & -13601 \\
\hline
\end{tabular}

Source: Author's calculation 
Although falling world oil price will lead to negative inflation in all economic sectors, imports value has been decreased but Iran's trade balance value has experienced export value decrease much more through decreasing imports in which the result is negative changing in trade balance.

The effect of policy shock on industry production: Table 3 shows the quantity of production in various sectors of industry and changing in them. Crude oil sector and other services are negatively affected by this policy shock. The production of heavy industry will increase and textiles will also experience 47 percent increase in production. Processed food section won't be affected by this policy changing.

Table 3: Changes in quantity of production in Iran's economic sectors qo

- in US Million \$

\begin{tabular}{|l|r|r|r|r|}
\hline \multirow{2}{*}{ Industry } & \multicolumn{2}{|c|}{ The quantity } & \multicolumn{2}{c|}{ Changes } \\
\cline { 2 - 5 } & Pre Shock & Post Shock & \multicolumn{1}{c|}{ Quantity } & \multicolumn{1}{c|}{ Percentage } \\
\hline Oil & 50019 & 41388 & 41388 & -17 \\
\hline MeatLstk & 18766 & 19661 & 19661 & 5 \\
\hline Extraction & 2941 & 3481 & 3481 & 18 \\
\hline ProcFood & 12304 & 12351 & 12351 & 0 \\
\hline TextWapp & 2750 & 4037 & 4037 & 47 \\
\hline LightMnfc & 14597 & 16795 & 16795 & 84 \\
\hline HeavyMnfc & 42148 & 77451 & 77451 & 5 \\
\hline Util_Cons & 40251 & 42419 & 42419 & 4 \\
\hline TransComm & 38108 & 39635 & 39635 & -5 \\
\hline OthServices & 47319 & 45122 & 45122 & \\
\hline
\end{tabular}

Source: Author's calculation

Market of production factors: according to GTAP model which uses factors fixedly and considers the price of factors variable, increasing the price of factors means increasing the demand for endowments and falling price vice versa means their unemployment. The table below shows that unemployment of labor will increase as the result of policy shock and using capital and natural resources will decrease. Of course the demand for land has been increased.

Table 4: Changes in price of endowments

- in percent (\%)

\begin{tabular}{|l|r|r|r|r|r|}
\hline \multirow{2}{*}{ Production Factors } & \multirow{2}{*}{ Land } & \multicolumn{2}{|c|}{ Labor } & \multirow{2}{*}{ Capital } & $\begin{array}{c}\text { Natural } \\
\text { Resources }\end{array}$ \\
\cline { 3 - 4 } & & Unskilled & Skilled & & -65.6 \\
\hline Price of Production Factors & 7.5 & -6 & -13 & -14.3 & -6.3 \\
\hline
\end{tabular}

Source: Author's calculation 
The consumer's welfare: regarding the variables related to the welfare, utility and equivalent variation is particularly important. Perceiving what factors caused changing welfare in Iran and its analysis is also considered important. Iranian households' per capita utility affected by policy shock has been decreased for more than 8 percent that is because of decreasing household utility of private sector for 7.7 percent and government sector as 7.8 percent. Decreasing the household income has been more than 18.5 percent that caused decreasing the household expenditures of private sector for 18.21 percent and its effect on decreasing household welfare is more than 8 percent. Decrease in equivalent variation also that is somehow considered as decrease in welfare is $12033.6 \mathrm{US}$ billion dollars. To investigate what factors create this decrease in welfare, Table 5 briefly shows analysis of welfare.

Table 5: Total changes in welfare and welfare decomposition in Iran

- in US Billion \$

\begin{tabular}{|c|c|c|c|c|}
\hline Components Effect & Allocative Efficiency & Terms of trade & I-S & Total \\
\hline Value & -1142 & -11112 & 217 & -12038 \\
\hline
\end{tabular}

Source: Author's calculation

Macroeconomic variable: among macroeconomic variables the variable which is the most important one is GDP and its components. Price index of gross domestic production ( $\mathrm{pgdp}$ ) has faced decrease more than 17 percent. Of course in all countries which export oil, negative inflation has been observed but this index in these countries has been around 8 percent. Second index is changing in the quantity of gross domestic production ( $q g d p$ ) of Iran that is about 1171 US million dollars (at the price of 1992) or about 0.7 percent and it has been followed by its negative growth. Ultimately the value of gross domestic production (vgdp) to the measure of two values above, has recorded 17.8 percent of decrease.

Falling oil price and income for oil exporting countries will directly lead to falling government income and following that it causes decreasing the consumption of government sector and as result it will change the combination of private and governmental sectors consumption. Therefore, other variables which changing in them is important and their combination is particularly important include the consumption of governmental and private sectors from domestic produced goods and imports. Through observing the table 7 , two subjects can be obviously seen. First the consumption of private and government sectors from both two types of imports and domestic produced has been decreased. Due to falling world oil price, its consumption from domestic production has been increased in private and government sectors and the import of both two sectors have been decreased. 
Table 6: Changes in private and public consumption combination in Iran

- in US Million \$

\begin{tabular}{|l|r|r|r|r|}
\hline \multirow{2}{*}{ Sectors } & \multicolumn{2}{|c|}{ Private consumption of } & \multicolumn{2}{c|}{ Public consumption of } \\
\cline { 2 - 5 } & $\begin{array}{c}\text { Imports } \\
\text { (qpm) }\end{array}$ & $\begin{array}{c}\text { Domestic production } \\
\text { (qpd) }\end{array}$ & $\begin{array}{c}\text { Imports } \\
\text { (qgm) }\end{array}$ & $\begin{array}{c}\text { Domestic production } \\
\text { (qgd) }\end{array}$ \\
\hline Oil & -14.6 & 5.2 & -3.6 & 20.1 \\
\hline MeatLstk & -25.3 & -4.0 & -20.6 & -34.8 \\
\hline Extraction & 70.6 & -13.9 & 29.4 & -7.8 \\
\hline ProcFood & -23.1 & -3.4 & -26.7 & -7.1 \\
\hline TextWapp & -19.5 & 9.8 & -31.9 & -1.3 \\
\hline LightMnfc & -24.3 & 2.3 & -26.9 & 31.6 \\
\hline HeavyMnfc & -42.6 & 12.0 & -32.5 & -2.2 \\
\hline Util_Cons & -26.5 & -5.5 & -23.9 & -5.8 \\
\hline TransComm & -29.9 & -7.8 & -28.4 & -6.9 \\
\hline OthServices & -29.2 & -9.1 & -27.6 & \\
\hline
\end{tabular}

Source: Author's calculation

The imports of private sector have been severely increased. Household consumption of private sector from domestic production of five economic sectors has been increased and it has decreased in other five sectors. Household consumption of private sector from imports except mining sector has decreased in all economic sectors and this decrease has been much more in heavy industries. The consumption of government sector from the imports of all economic sectors has been decreased and the consumption of domestic production except little amount of increase in livestock and agricultural sector, has decreased in all economic sectors. Generally, decreasing the consumption of governmental sector is comprehensive and main weight of decreasing consumption is on import goods. In private sector also the consumption from imports has generally decreased but the consumption of domestic production isn't much more different from before falling world oil price.

\section{Results and discussion}

The main aim of this paper was to assess the impacts of oil price reduction on Iran's economy trade related variables, labor and production's factor market, economic sectors' production, public and private sectors' consumption, utility and welfare. In this policy simulation, exporting crude oil and mining sector have been faced with the greatest decrease (more than $70 \%$ ). Trade balance in these two sectors is severely negative and also total trade balance of Iran is negative. This trade policy has significantly affect Iran's trade texture. Decreasing the price of export goods will have negative effect on economy in terms of two aspects. First it causes decreasing supply and demand of commodities and secondly through selling 
previous quantities of goods, less amount of income will be gained for Iran that the waves of this negative effect will be much more in dynamic mode. Neamatollahi and Majdzadeh Tabatabaei (2009) believe that each negative shock (positive or negative) will negatively affect Iran's trade balance but the study of Arani et al. (2010) has showed that in oil-rich countries, only negative shock has negative effect on current account of these types of countries.

Secondly, the results show that falling oil price will have the most important negative effect on producing oil and services. Through falling oil price, foreign currency resources will severely decrease for investment in oil sector and it will lead to decreasing production of this sector. Decreasing oil incomes will also have some effects on services of public and private sectors. Government's income decrease from oil will lead to decrease in proposing health, welfare, and educational services and even consuming and production subsidies and in addition to decrease in governmental services, it will have negative effect on the services of private sector. GDP quantity will decrease by 0.7 percent and the value of GDP will decrease for 17.8 percent. Economy situation of Iran shows that, recession depth and unemployment rate have been increased. This phenomenon can be seen in most of oil-rich countries.

Empirical studies of Motevaselli and Fouladi (2006) have shown same direction of oil prices and the change in GDP of Iran. Iran and UAE economy have shown the most dependency on oil according to the study of Jahadi and Elmi (2011). In the market of production factors also, falling oil price has decreased the demand for labor, capital and natural resources. The most decrease of demand has happened for natural resources and skilled labor. Following decrease in GDP, demand for production factors will also decrease. Technology tree and the function of added value and final goods will lead this phenomenon. Samadi et al. (2013) believe that each type of fluctuation in oil price will affect negatively on labor market and investment in Iran.

Regarding that most government services and its transferred payments are financed through oil income, the welfare of Iranian households is severely dependent on oil price. Falling oil price has had the effect of 12 billion dollars on the welfare of households in Iran that heavy volume of that refers to terms of trade. Lack of efficient allocation is in second rank of negative effect on welfare and welfare related to the saving-investment has increased. The study of Hassanzadeh et al. (2012) showed that urban household expenditure and welfare are the effects of oil price fluctuations.

Another effect of falling oil price is changing the combination of government and private sector's consumption. It can be said that the government has generally decreased the consumption and private sector consumption has experienced less decrease. The results are similar to the results of Ghiasvand and Yahoo (2010). 


\section{Conclusion}

The problems of Iranian economy began with the fall in oil prices. Some speculations linked these problems with international sanctions against Iran, and some with decline in oil prices. Using a GTAP model approach, this study has confirmed that oil price reduction has a negative impact on Iranian consumption, utility, and welfare, demand for labor, GDP and sectors' production as well as on Iranian export and import. Furthermore, it has changed private and public consumption combination significantly. Welfare decomposition showed that terms of trade was affected dramatically. This study, in a policy simulation and using relatively new approach, evaluated the most important variables influenced by the fall in oil prices, but there were two limitations related to the model: first, the static model was used to study the effect of oil price decline on all variables; the dynamic model shows the effects more accurately, second, the model's data for Iran is not up-to-date, so the results of this research are not completely accurate. Therefore, we believe that the future studies on oil price and its impacts, should be done by using dynamic models and up-to-date data. In addition, this study suggests that Iranian policymakers should focus on rising oil price at the international level and OPEC, and, moreover, to increase the ability of the Iranian economy to resist the effects of lowering oil price.

\section{References}

Abrishami, H. et al. (2009) "The relationship between oil shocks and economic growth in OPEC member countries, whether the relationship is symmetrical?", Quarterly Energy Economics Review, Vol. 22, pp. 201-229.

Afshari, Z. (2013) Economic Planning. Tehran, Iran: SAMT.

Arani, A. et al. (2010) "The effect of oil price shocks on the current account of OPEC member states", Quarterly Journal of Quantitative Economics, Vol. 7, No. 3, pp. 1-21.

Baffes, J. et al. (2015) "The great plunge in oil prices: Causes, Consequences, and policy responses", SSRN Electronic Journal, PRN/15/01, World Bank Group, pp. 1-61, doi: 10.2139/ssrn.2624398.

Behboudi, D. et al. (2009) "Oil prices destabilizing effects on GDP in Iran", Quarterly Energy Economics Review, Vol. 6, No. 20, pp. 1-33.

Bodenstein, M., Guerrieri, L., Gust, C. J. (2013) "Oil shocks and the zero bound on nominal interest rates", Journal of International Money and Finance, Vol. 32, pp. 941-967, doi: 10.1016/j.jimonfin.2012.08.002.

Delavari, M. et al. (2009) "The effect of oil prices on economic growth in Iran using asymmetric convergence", Quarterly Energy Economics Review, Vol. 5, No. 18, pp. $65-80$. 
Dreger, C., Teymur, R. (2014) "The Impacts of Oil Revenues on the Iranian Economy and the Gulf States", SSRN Electronic Journal, doi: 10.2139/ssrn.2432957.

Ebrahimi, M. et al. (2010) "Oil price fluctuation impacts on macro variables of Iran's economy." The Economic Policies (Name-ye-Mofid), Vol. 78, No. 5, pp. 89-106.

Emami, K., Mehdi, A. (2012) "Oil income shocks and economic growth in Iran", Economic Modeling, Vol. 29, No. 5, pp. 1774-1779, doi: 10.1016/j. econmod.2012.05.035.

Esmailipour Masoule, E., Shamsollah, S., Ilnaz, E. (2017) "The effect of external shocks on Iran's oil economy: a DSGE-BVAR approach", Quarterly Journal of Applied theories of Economics, Vol.4, No. 2, pp. 49-78. <http://ecoj.tabrizu.ac. ir/>.

Farzanegan, M. R. (2011) "Oil Revenue Shocks and government spending in Iran", Energy Economics, Vol. 33, No. 6, pp. 1055-1069, doi: 10.1016/j. eneco.2011.05.005.

Ghiasvand, A., Masoud, Y. (2010) "Asymmetric effects of oil price changes on consumption of private and government of Iran", Journal of Economics, Vol. 2, No. 5, pp. 31-52.

Gozali, M. (2011) "Macroeconomic impacts of oil price levels and volatility on Indonesia." Undergraduate Economic Review, Vol. 7, No. 1, Article 4, <http:// digitalcommons.iwu.edu/uer/vol7/iss1/4>.

Hasanzadeh, M. et al. (2012) "The effects of oil price volatility on the welfare of households: general equilibrium model", The Economic Research (Scientific Research Quarterly), Vol. 12, No. 4, pp. 55-77.

Hertel, T. W. (1997) Global Trade Analysis: Modeling and application, Cambridge University Press.

Jahadi, M., Zahra, E. (2011) "Oil price shocks and economic growth (Evidence of OPEC)", Quarterly Journal of Economic Growth and Development Research, Vol. 1, No. 2, pp. 11-40.

$\mathrm{Ju}$, K. et al. (2016) "Macroeconomic performance of oil price shocks: Outlier evidence from nineteen major oil-related countries/regions", Energy Economics, Vol. 60, pp. 325-332, doi: 10.1016/j.eneco.2016.10.009.

Mahmoodi, A. (2015) "Global trade analysis project". Islamic Azad University, Tehran, Iran.

Mehragan, N. et al. (2013) "Several behavioral pattern of economic growth in response to fluctuations in crude oil prices", Journal of Economic Modeling Research, Vol. 12, pp. 73-101.

Mehrara, M., Kameran, N. O. (2006) "Oil shocks and its dynamic effects on macroeconomic variables", Iranian Journal of Trade Studies, Vol. 6, No. 40, pp. 1-33. 
Memarzadeh, A., Nasser, Kh. (2017) "Investigating dynamic effects of structural shocks in global oil market on Iran's public and private sector expenditure: Structural Dynamic Model Approach", Applied theories of Economics, Vol. 4, No. 2, pp. 169-1194. <http://ecoj.tabrizu.ac.ir>.

Monjazeb, M., Ali, S. Zahrz, S. (2013) "The effects of oil price shocks on economic growth (Case study: Selected oil exporting countries)", Technical Journal of Engineering and Applied Sciences, Vol. 3, No. 13, pp. 2118-2122. Available at: $<$ http://www.tjeas.com/wp-content/uploads/2013/09/2118-2122.pdf $>$.

Moqaddam, M., Mohammad Reza, S. (2012) "The effect of World oil prices on macroeconomic variables in Iran", The Economic Research, Vol. 12, No. 47, pp. $197-216$.

Motavasseli, M., Maasoumeh, F. (2006) "The effects of increased oil prices on GDP and employment in Iran using a CGE Model", Journal of Economic Research, Vol. 76, pp. 51-76.

Neamatelahi, F., Sharareh, M. T. (2009) "The effects of OPEC oil price changes on trade balance of Iran", Journal of Economic Modeling, Vol. 10, No. 3, pp. 151169.

Nusair, S. A. (2016) "The effects of oil price shocks on the economics of the Gulf Co-operation council countries: Nonlinear analysis", Energy Policy, Vol. 91, pp. 256-267, doi: 10.1016/j.enpol.2016.01.013.

Pashaeifam, R., Mohammadreza, P., Patrice, A. (2013) "Explanation and Analysis of the impacts of OPEC's oil price fluctuations on inflation of oil-importing countries of the OECD", Quarterly Journal of The Economic Development Research, Vol. 9, pp. 89-116.

Rabie Hamadani, H. R., Mehdi, P. (2015) "Wealth and economic burden of oil price shocks on the economy of Iran: A New Keynesian approach", Journal of Economic Research and Policies, Vol. 22, No. 4, pp. 223-246.

Sadeqi, S. K. et al. (2013) "The Effects of Volatility of oil prices on GDP growth in Iran: Markov-Switching model analysis", Quarterly Journal of Applied Economics Studies in Iran (AESI), Vol. 2, No. 5. pp. 29-52. <https://aes.basu. ac.ir/article_390.html >.

Saeideye, B. (2004) The effect of a negative shock of oil production on macroeconomic variables of economic sectors in Iran Economic Institute, Master of Science, Shahid Bahonar University.

Salehi Esfahani, H., Kamiar, M., Mohammad Hashem, P. (2009) "Oil Exports and the Iranian Economy”, SSRN Electronic Journal, I. D. N. 4537. Bonn, Germany, Institute for the Study of Labor, doi: 10.2139/ssrn.1849563.

Samadi, A.H., Ebrahim, H., Mahboubeh, J. (2013) "The effect of permanent and temporary fluctuations in oil prices of OPEC on investment, production and unemployment in Iran", Journal of Iranian Energy Economics, Vol. 2, No. 7, pp. 75-101. <http://fa.journals.sid.ir/ViewPaper.aspx?id=216785>. 
Samadi, S., Abolfazl, Y. A., Noushin, M. (2009) "Analyze the impact of oil price shocks on macroeconomic variables in Iran", Journal of Economic Research and Policies, Vol. 17, No. 52, pp. 5-26. < http://qjerp.ir/article-1-307-fa.pdf >.

Shariati, A., Mehrdad, M., Sayed Yaaqub, Z. K. (2013) "The relationship between long-term volatility of stock indexes and oil prices with economic growth in member countries of D-8". The first national e-conference of economic outlook for Iran with a view to support production, 19 December, Khorasegan, Iran.

U.S. Energy Information Administration (2017). What drives crude oil prices? An analysis of 7 factors that influence oil markets, with charts data updated monthly and quarterly. Washington, DC, U. S. E. I. Administration. Independent Statistics \& Analysis.

Wang, Q., Li. R. (2016) "Impact of Cheaper Oil on Economic System and Climate Change: A SWOT Analysis", Renewable and Sustainable Energy Reviews, Vol. 54, pp. 925-931, doi: 10.1016/j.rser.2015.10.087.

Zhao, L., Zhang, X., Wang, S., Xu, S. (2016) "The effects of oil price shocks on output and inflation in China", Energy Economics, Vol. 53, pp. 101-110. doi: 10.1016/j.eneco.2014.11.017. 


\title{
Utjecaj smanjenja cijene nafte na iransko gospodarstvo $^{1}$
}

\author{
Abdollah Mahmoodi ${ }^{2}$
}

\begin{abstract}
Sažetak
Cilj ovoga rada je istražiti utjecaj smanjenja cijena nafte na iransko gospodarstvo. Za simuliranje šoka, analiziraju se podaci uz primjenu modela GTAP-a (Global Trade Analysis Project). U novo prikupljenoj skupini podataka o izvozu nafte u Iranu i ostalim zemljama svijeta kao novim gospodarskim regijama, stvoreno je deset novih razvijenih gospodarskih sektora, u koje su agregirani nafta kao jedan sektor $i$ pet resursa čimbenika proizvodnje. Umjesto standardnog modela zatvorenog gospodarstva, pad cijene svjetske nafte simuliran je modelom politike šoka. Rezultati pokazuju da će prihodi od izvoza nafte i izvozne vrijednosti mineralnih proizvoda biti smanjeni, ali će se povećati izvoz ostalih proizvodnih sektora. Na trgovinsku bilancu Irana to bi negativno $i$ snažno utjecalo kao $i$ dovelo do pada proizvodnje nafte $i$ ostalih usluga. Na tržištu proizvodnih sektora, potražnja za radnom snagom, prirodnim resursima $i$ investicijama dramatično se smanjuje, a potražnja za zemljištem povećava. Korištenjem ekvivalentne varijacije (EV), vidljive su negativne promjene koje utječu na blagostanje Irana. I na kraju, deflacija, smanjenje vrijednosti, pad BDP-a i promjene u potrošnji kombinirane vrijednosti od javnog do privatnog sektora predstavljaju dodatni gospodarski utjecaj Irana na pad cijene nafte. Predlaže se da buduće studije budu provedene uz korištenje dinamičkih modela $i$ ažuriranih podataka, a preokret kreatora politike treba biti usmjeren na povećanje cijena nafte na međunarodnoj razini i unutar OPEC-a.
\end{abstract}

Ključne riječi: cijena nafte, iransko gospodarstvo, potrošnja kombinirane vrijednosti, blagostanje, tržište rada

JEL klasifikacija: F17, I30, J23, Q31, C68

1 Ovo istraživanje financirano je od strane ogranka sveučilišta Mahabad Branch of Islamic Azad University u okviru programa "Samostalni istraživački projekti Islamskog Sveučilišta Azad", šifra 51662931101001, broj ugovora 02-29-5/678.

2 Docent, Mahabad Branch, Islamic Azad University, Collage of Humanities, Pazhuhesh sq, Mahabad, Western Azerbaijan, Iran. Znanstveni interes: ekonomija. Tel.: +98 9144420209 , E-mail:mahmoodi_a2000@yahoo.com. 